Global Conferences Series:

Social Sciences, Education and Humanities (GCSSSEH), Volume 2, 2019

The $2^{\text {nd }}$ International Conference on Sustainable Development \& Multi-Ethnic Society

DOI: https://doi.org/10.32698/GCS.0181

\title{
The Mastery of HOTS of History Learning Amongst Pupils in Rural Area
}

\author{
Matinah Mupin ${ }^{1}$, Mohd Mahzan Awang ${ }^{2}$, Abdul Razaq Ahmad ${ }^{3}$, Anuar Ahmad ${ }^{4} \&$ \\ Shakila Che Dahalan ${ }^{5}$ \\ ${ }^{1}$ SK Bunga Raya, MALAYSIA \\ ${ }^{2345}$ Faculty of Education, MALAYSIA \\ E-mail: $\underline{\text { m_icha26@yahoo.com }}$
}

\begin{abstract}
A proficient way of thinking among the student is the main key to create innovative, creative and skillful pupils in order to fulfil the needs of the country in order for it to be recognized and able to compete with any other countries especially in 21 st century. The school curriculum which is run by teachers plays an important role in order to lead the pupils and make them able to apply the Higher Order Thinking Skills (HOTS) in their studies. HOTS is an important aspect in teaching and learning methods that had been introduced for education purposes in Malaysia. Students with HOTS are able to learn, improve their performance and reduce their weaknesses in their studies. To be more concern about its application in daily learning at schools, especially in particular subject like History, HOTS is not well applied in primary school especially in rural areas. Thus, this paperwork is being conducted to observe the application of HOTS in daily learning and the ability of the pupils to cope with the system especially in primary schools in rural areas which most of the pupils are only from two different races, which are Dusun and Murut. This paperwork is also done as the suggestive methods to help the school and Ministry of Education in planning and preparing the methods that can be used for the application of HOTS in primary schools in rural areas particularly in learning of History subject.
\end{abstract}

Keywords: HOTS, history subject, primary school, rural area

\section{Introduction}

The Malaysian Education Development Plan (PPPM) 20132025 is a government effort to ensure that education in Malaysia is in line with the global educations. The 20132025 PPPM outlined six key features that students need to have in order to compete with the global education system in the fields of knowledge, leadership skills, thinking skills, bilingual skills, ethics and spirituality and national identity.
In order to meet the rapid pace of technology, students need to master creative thinking, critical thinking and reasoning as well as good learning ability (KPM, 2013). HOTS are an initiative by the Ministry of Education Malaysia (MOE) to produce balanced and responsible generations for national development. Implementing highlevel thinking skills can help students develop their thinking skills and improve achievements. HOTS are an approach that 
teachers need to use in the teaching and learning processes which aimed in developing a generation of highly skilled thinkers to meet the challenges of the 21 st century.

Bloom's Taxonomy outlines two levels of thinking skills: Lower Order Thinking Skills (LOTS) and Higher Order Thinking Skills (HOTS). LOTS involve the cognitive level of knowledge, understanding and application while HOTS involves the cognitive level of analysis, synthesis and evaluation. HOTS are closely linked to critical and creative thinking skills. HOTS refers to more than just reading, writing and counting but in a competitive world, students need to do more than just memorize or tell all the facts. Students need to be able to understand facts, relate to each other and use them to solve problems.

The emphasis of HOTS in the Standard Curriculum for Primary School (KSSR) and Standard Curriculum for Secondary School (KSSM) is an effort to strengthen thinking skills so that students not only memorize but understand what they are learning, draw conclusions and reflection and then apply such knowledge in real life situations (Bahagian Pembangunan Kurikulum, 2014).

The application of HOTS in teaching and learning today is evaluated by reference to students' ability to apply critical thinking when solving problems. In addition, the application of these HOTS also requires the ability to reduce confusion and increase students' interest in teacher-assigned tasks. Teachers' support in encouraging students to think openly to express ideas can also helps students to develop their HOTS.

The History subject of Primary School has been introduced by the MOE in all national schools (Sekolah Kebangsaan and Sekolah Rendah Jenis Kebangsaan) over the last five years, in 2014 from year 4 to year 6 (also known as Standard (Darjah) 4 to 6). The History subjects introduced were efforts coincide with fostering the values of patriotism and nationalism among students. Previously historical elements were only applied to the subjects of Local Studies but with the implementation of History subjects in primary schools, the teaching and learning of the subject were focusing more on the source and appreciation of the history itself and gave students a deeper understanding and appreciation to students of the homeland while recognizing the statesmen who served their homeland long ago until the Malaysia existed.

Through the Standard Curriculum of Primary School (KSSR) for Primary School history subjects, students will be given exposure to critically analyze and evaluate historical facts. The curriculum is based on six pillars of Communication, Spirituality, Attitude and Values,
Humanities, Science and Technology Literacy and Personal Skills. These six pillars are values that support each other and are integrated with the building blocks of HOTS.

Hence, it is required for all teachers in primary schools able to use their creativity to diversify the methods and techniques of teaching and learning. History subjects in and out of the classroom has to be done as to make them more engaging, effective, tedious and engaging students, besides being easy to be understood especially in rural primary school students with different levels of thinking ability.

\section{Problem Statement}

The contents of the History curriculum contain many solid facts such as events, characters and dates that students need to remember. As a result, this subject is of little interest to students and students simply memorize without evaluating the historical facts (Hartini Husain, 2006). The emphasis on one-way interactions and memorization techniques on facts makes history "the dead man of curriculum" (Anuar Ahmad, Siti Haishah Abd Rahman \& Nur Atiqah T. Abdullah, 2009). The negative attitude of teachers is causing them to fail to grasp the minds of students to think critically and to generate new ideas. Through PPPM (2013-2025), History education has been emphasized to ensure that one of the six aspects of students' thinking skills can be applied to students.

According to Nooraini Othman \& Khairul Azmi (2014), the issue of thinking skills has been widely discussed and debated by educators and educational leaders. A study conducted by Saemah and Zamri (2017) which examining students' reaction and achievement can serve as a benchmark in improving teaching and learning methods based on HOTS. This study also found that the methodology for the integration of knowledge in the syllabus and the implementation of teaching methods based on HOTS are in line with critical thinking-based teaching methods.

Teachers' understanding of the concept of HOTS greatly influences the effectiveness of students' learning. According to the Kestrel Education (UK) and 21 Century Schools (USA) Consultative Needs Study Report in the 2013-2025 PPPM Report (KPM 2103), teachers' knowledges of HOTS in teaching and learning are still low and requires changes for curriculum innovation that was planned by the Ministry of Education Malaysia. This finding is supported by a study by Nor Hasmaliza (2016) and Rahimah (2016) who found that teachers still lack of understandings and knowledges of HOTS.

According to Zamri (2015), teachers who still use traditional methods irrespective of their HOTS greatly 
influences student achievement, and even to excel in any subject is also difficult. Teaching that is still a teachercentered traditional teaching is one of the obstacles in realizing students' thinking skills. This will enable students to become passive learners in the process of teaching and learning. Siti Zubaidah (2006) states that passive students' behavior can be overcome by establishing active interactions between teachers and pupils, pupils and pupils and the use of teaching aids. At the same time, it also gives us a little more freedom to think creatively through student engagement and facilitates student in sharing of ideas.

Teaching and learning that is still subject to examination is one of the issues in the research problem statement. It has undermined efforts to produce students intellectually, spiritually, emotionally and physically balanced as embodied in the contents of the National Education Philosophy (Falsafah Pendidikan Kebangsaan). This situation is causing teachers to focus less on students' thinking skills as they focus more on their own syllabus. From the experience of the researcher himself, since this subject is not a core subject in primary school, teachers are only conducting teaching and learning which is a subject to examination. It is also the attitude of the students who consider the History subject to be unimportant which makes them less desirable because their achievement in the examination for the History subjects does not affect their overall performance in the midterm or end-of-year examinations.

As such, teachers play an important role in ensuring that the curriculum is implemented as changes have to be implemented in the history teaching processes by conducting teaching and learning that emphasize the use of high-level thinking skills. Researchers believe that the use and mastery of HOTS is one of the best ways to attract students' attention and interest in studying History subjects.

Characteristics of students who master HOTS are inquisitive and can suggest solutions based on existing knowledge. The use of materials such as high-level questions can encourage students to think deeply, draw conclusions and reflections and then apply that knowledge to real situations (Bahagian Pembangunan Kurikulum, 2014).

Previous research has been focusing more on the application of HOTS among history teachers in secondary schools but did not focus on rural primary school teachers. Until now, there have been no clear comparisons between rural primary school students of Dusun and Murut who have been the study sample in terms of utilization and mastery of HOTS in History learning. To what extent is the readiness of rural Primary school teachers to practice HOTS in teaching? What is the attitude of rural primary students towards the use and mastery of HOTS in learning? The study will focus on rural school history teachers as well as rural primary school students from Dusun and Murut students located in Keningau, Sabah.

\section{Theory and Definition of HOTS}

HOTS are defined as the ability to apply knowledge, skills and values in solving problems, making decisions, innovate and be able to create something (Bahagian Pembangunan Kurikulum, 2013). HOTS are a widely used mindset for coping with new challenges (S. Supramani, 2006). According to Zevin (1999) in Musliha Salma (2010), highlevel thinking is an extension of information that is constantly in mind to create something new and original. One of the key components of creative and critical thinking skills (Heong, 2011).

Students will use HOTS to analyze, comparing, formulating, interpreting, evaluating and generating ideas when assigned a task to solve (Quellmaz, 1985). HOTS occur when an individual receives new information, processes it, makes subsequent judgments and resolves problems that are not uncommon (Lewis and Smith, 1993). Next, HOTS involve higher cognitive skills which include analyzing, synthesizing, evaluating and generating new ideas (Tomei, 2005). In order to improve the HOTS, questioning technique is very important. Benjamin Bloom developed the Bloom's Taxonomy Theory in the 1950s. This theory is a sixstage hierarchy of developmental thinking that is becoming more complex and challenging. Lorin Anderson, a student of Benjamin Bloom, made improvements to the original taxonomic theory in the 1990s (Lembaga Peperiksaan Malaysia, 2013)

DIAGRAM 1: Hierarchy Anderson (2001)

$\uparrow \begin{aligned} & \text { Creating } \\ & \text { Evaluating } \\ & \text { Analyzing } \\ & \text { Applying } \\ & \text { Understanding } \\ & \text { Remembering }\end{aligned} \longrightarrow$ HOTS


DIARGAM 2: Adapted from Anderson et. al (2001)

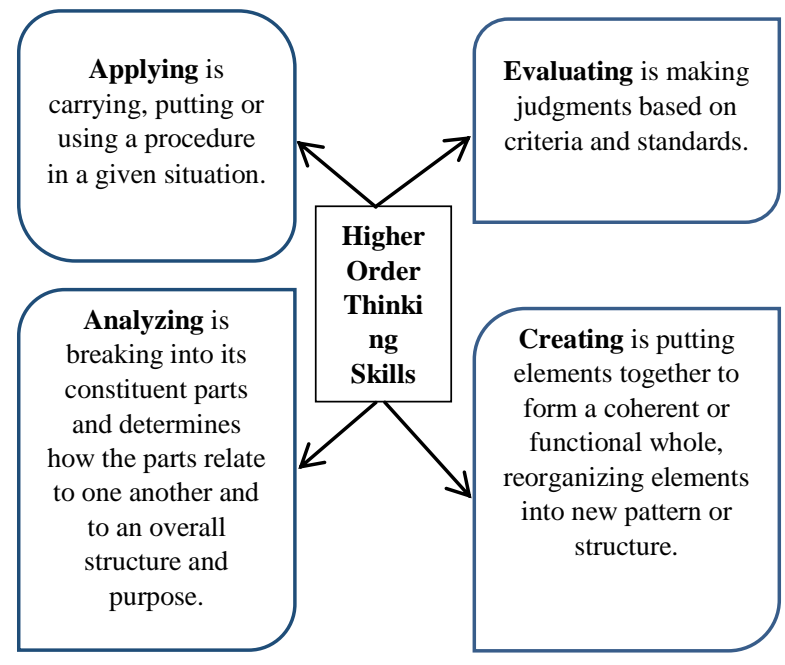

TABLE 1: Examples of HOTS in Curriculum Standard and Primary School Assessment Documents (DSKP) Year 4 for History Subject. Source: KPM (2014)

\begin{tabular}{|c|c|c|c|c|}
\hline $\begin{array}{l}\text { Standard } \\
\text { Contains }\end{array}$ & $\begin{array}{c}\text { Examples of } \\
\text { Applying } \\
\text { Questions }\end{array}$ & $\begin{array}{c}\text { Examples } \\
\text { of } \\
\text { Analyzing } \\
\text { Questions }\end{array}$ & $\begin{array}{c}\text { Examples } \\
\text { of } \\
\text { Evaluating } \\
\text { Questions }\end{array}$ & $\begin{array}{c}\text { Examples } \\
\text { of } \\
\text { Creating } \\
\text { Questions }\end{array}$ \\
\hline $\begin{array}{l}\text { Understand } \\
\text { ing History } \\
\text { and } \\
\text { Historical } \\
\text { Skills }\end{array}$ & $\begin{array}{l}\text { How do you } \\
\text { draw on a } \\
\text { historical } \\
\text { event based } \\
\text { on the } \\
\text { timeline? }\end{array}$ & $\begin{array}{l}\text { Why is it } \\
\text { important } \\
\text { to study } \\
\text { history? }\end{array}$ & $\begin{array}{l}\text { What is the } \\
\text { importance } \\
\text { of studying } \\
\text { History? }\end{array}$ & $\begin{array}{l}\text { What are } \\
\text { some steps } \\
\text { that can be } \\
\text { taken to } \\
\text { preserve } \\
\text { the nation's } \\
\text { heritage? }\end{array}$ \\
\hline $\begin{array}{l}\text { Self- } \\
\text { understand } \\
\text { ing and } \\
\text { family } \\
\text { understand } \\
\text { ing }\end{array}$ & $\begin{array}{l}\text { Based on the } \\
\text { family calling } \\
\text { system, } \\
\text { complete the } \\
\text { dialog below } \\
\text { based on the } \\
\text { timeline. }\end{array}$ & $\begin{array}{l}\text { What is the } \\
\text { difference } \\
\text { between } \\
\text { basic } \\
\text { family and } \\
\text { extended } \\
\text { family? }\end{array}$ & $\begin{array}{l}\text { Why is the } \\
\text { family } \\
\text { system } \\
\text { important } \\
\text { in the } \\
\text { family? }\end{array}$ & $\begin{array}{l}\text { What do } \\
\text { you think } \\
\text { of the rules } \\
\text { that can be } \\
\text { practiced in } \\
\text { your } \\
\text { family? }\end{array}$ \\
\hline $\begin{array}{l}\text { School } \\
\text { History }\end{array}$ & $\begin{array}{l}\text { How do you } \\
\text { outline your } \\
\text { school history } \\
\text { using the } \\
\text { timeline? }\end{array}$ & $\begin{array}{l}\text { How does } \\
\text { your } \\
\text { school } \\
\text { succeed in } \\
\text { co- } \\
\text { curricular } \\
\text { achieveme } \\
\text { nt? }\end{array}$ & $\begin{array}{l}\text { Why you } \\
\text { should be } \\
\text { proud of } \\
\text { your } \\
\text { school's } \\
\text { history? }\end{array}$ & $\begin{array}{l}\text { Describe } \\
\text { what can be } \\
\text { done to } \\
\text { keep your } \\
\text { school's } \\
\text { history } \\
\text { alive? }\end{array}$ \\
\hline $\begin{array}{l}\text { Student } \\
\text { Residence } \\
\text { Area }\end{array}$ & $\begin{array}{l}\text { Why is the } \\
\text { riverfront } \\
\text { area no longer } \\
\text { an option for } \\
\text { settlements? }\end{array}$ & $\begin{array}{l}\text { How much } \\
\text { of your } \\
\text { heritages is } \\
\text { your tourist } \\
\text { attraction? }\end{array}$ & $\begin{array}{l}\text { Why you } \\
\text { should be } \\
\text { proud of } \\
\text { your home } \\
\text { history? }\end{array}$ & $\begin{array}{l}\text { How do } \\
\text { you } \\
\text { maintain } \\
\text { your } \\
\text { heritage? }\end{array}$ \\
\hline
\end{tabular}

The Malaysian Examination Board (2013) defines HOTS as the process of using the mind to find the meanings and understanding something, exploring various ideas or creations, making decisions and solving problems and then reflecting and meta cognitively about the process.
HOTS allow students to think deeply, consistently, productively and effectively. Thinking is an important aspect of students' ability to transfer their learned skills to other situations. In addition, students are able to control, determine the direction, measure the progress of their lessons and using the knowledge they have learned more productively. HOTS also apply critical thinking, creative thinking, logical thinking, reflective and meta cognitive thinking. Thus, students are able to absorb any data or information that is then processed into the mind and eventually reproduced in various forms (Rajendran Nagappan, 2014).

\section{Literature Review}

A case study conducted by Bavani A/P Nandakumal (2016), which identified HOTS among fourth grade students through learning History showed that mastery of HOTS among students was minimal and most teachers were unclear on how to apply elements of HOTS in the process of teaching and learning. Teaching plans involving HOTS are not provided but some do not include the objectives of thinking skills in the Daily Learning Plan.

In addition, according to Kartini (1998) in her study Critical Thinking Skills in Teaching History: Review and Related Research to review aspects of strategy and learning, classroom organization and interaction, examine teacherrelated dilemmas to encourage students to think critically as well as perceptions teachers of the thinking skills teaching programs implemented in schools, found that teacher centered teaching activities were most prominent while students played a passive role in listening more. She also found that many factors that teachers perceived as challenging and hindered teaching of critical thinking such as curriculum content and exams were too narrow and time limited to subjects, emphasis on good student outcomes, lack of appropriate teaching materials, the burden of heavy teacher work and time are required as preparations for critical thinking skills, teaching activities, student ability in language and reading skills.

The learning environment is consistent where learning and assessment are based on the purpose of teaching that is in conflict with the teaching practice proposed in the HOTS teaching program (Rajendran, 2001). She also found that teachers did not mention HOTS in their teaching and learning.

Mohamad Nurul Azmi Mat Nor (2016) in a study conducted on the mastery of HOTS among Primary School Design and Technology (Reka Bentuk dan Teknology) teachers, found that the level of HOTS elements of teachers in the teaching and learning process was still at a moderate 
level. Teachers are still not sure about using Bloom's Taxonomy as a HOTS foundation.

In addition to the research conducted by Nur Hawa Hanis (2018), teachers' readiness to implement Higher Thinking Skills in teaching, shows that the level of readiness of history teachers in implementing HOTS in teaching is modest. She also found that the teachers' attitude towards the implementation of HOTS in teaching was positive. The level of teachers' knowledge is closely related to teachers' experiences. This means that teachers are aware of the importance of HOTS as they only need more time and training to increase their knowledge and skills in HOTS.

Rajendran (2001) in his study found that teachers are still tied to the old style of teaching without mentioning critical and creative thinking skills in teaching. Rajendran (2008) further elaborated on the constraints faced by teachers in applying HOTS in teaching and learning, such as lack of exposure to knowledge in this area, teachers' unwillingness to apply high level thinking skills in their teaching and learning, more curriculum policies to the examination thus, ignoring the thinking skills and pedagogical approach of teaching and learning are less effectively applied in HOTS.

A study conducted by S. Supramani (2006) is to look at teacher questioning techniques for students. The results of data analysis on teacher questions and student responses during teaching and learning English provide a clear indication that most teachers have a tendency to ask lower-level cognitive questions or convergent questions than high-level cognitive questions or divergent questions.

Hong et.al (2010) in his study described the use of high-level thinking skills through Marzano's approach in Technical and Vocational subjects. Marzano's approach is the skills of comparing, classifying, inductive and deductive in project idea generation for technical subjects.

\section{Suggestions}

The process of teaching and learning History subjects still has a room to improve and to increase the HOTS in rural primary school students. Therefore, it is recommended for certain parties based on past studies involving teachers, committee chairmen and administrators for the school. Teachers should first have specific characteristics of critical thinking, creative, reflective, proactive and knowledgeable to implement teaching involving high school thinking skills.

Teachers should learn how to change and learn to implement change where teachers must be prepared to accept new challenges and shifts in education and not adhere to past teaching techniques. Teachers should take self enrichment initiatives with HOTS by attending programs developed under the PPPM. In addition, sharing in the Professional Learning Community (PLC) is also one of the ways for teachers to improve their knowledge and skills in high level thinking skills.

Teachers should also make sure that students are prepared and able to answer everything related to HOTS by presenting HOTS items in a more attractive form. Students should also be familiar with various HOTS during assessment in the classroom. Teaching and learning should be transformed into learning and facilitating where teachers play a role and students learn during low level activities and when they reach high levels, teachers will change to facilitators during the learning process.

Future studies can be extensively conducted to examine the level of mastery of HOTS among rural school students for other subjects involving study samples namely from year 1 to year 6 students in primary school.

\section{References}

[1] Anuar Ahmad, Siti Haishah Abd Rahman \& Nur Atiqah T. Abdullah. 2009. Tahap Keupayaan Pengajaran Guru Sejarah dan Hubungannya dengan Pencapaian Murid di Sekolah berprestasi rendah. Jurnal Pendidikan Malaysia, 34 (1), 53-66.

[2] Bahagian Pembangunan Kurikulum. 2014. Kemahiran Berfikir Aras Tinggi Aplikasi di Sekolah. Kuala Lumpur: Kementerian Pendidikan Malaysia.

[3] Baharuddin Bin Jabar. 2006. Perspektif Pelajar Terhadap Pengajaran Kemahiran Berfikir Aras Tinggi dalam Pengajaran dan Pembelajaran di Sekolah Menengah: Satu Kajian Kes di Daerah Hilir Perak. Fakulti Sains Sosial dan Kemanusiaan: Universiti Pendidikan Sultan Idris Perak.

[4] Bavani A/P Nandakumal. 2016. Penguasaan Kemahiran Berfikir Aras Tinggi Melalui Pembelajaran Mata Pelajaran Sejarah Dalam Kalangan Pelajar Tingkatan Empat: Satu Kajian Kes. Fakulti Pendidikan dan Pembangunan Manusia: Universiti Pendidikan Sultan Idris.

[5] Caroline. D \& Abdul Said Ambotang. 2014. Profesionalisme Guru Novis dalam Pengurusan Pengetahuan, Kesediaan Mengajar dan Kemahiran Berfikir Aras Tinggi (KBAT) terhadap Pelaksanaan Pengajaran di Sekolah. Fakulti Psikologi dan Pendidikan: Universiti Malaysia Sabah.

[6] Chew Fong Peng \& Shashipriya Nadaraja. 2014. Pelaksanaan Kemahiran Berfikir Kreatif dan Kritis Dalam Pengajaran dan Pembelajaran Komsas di Sekolah Menengah. Jurnal Pendidikan Bahasa Melayu. ISSN: 2180-4842. vol. 4, Bil. 2 
[7] Hartini Husain. 2006. Achievement and Attitudes of Students in Teaching the Subject through a Computer. (Unpublished Master Dissertation). University Kebangsaan Malaysia, Malaysia.

[8] Kartini Baharun. 1998. Kemahiran Berfikir Kritis dalam Pengajaran dan Pembelajaran Bestari. Bahagian Pendidikan Guru. Kementerian Pelajaran Malaysia

[9] Kassim, N. \& Zakaria. E. 2015. Integrasi Kemahiran Berfikir Aras Tinggi dalam Pengajaran dan Pembelajaran Matematik: Analisis Keperluan Guru. Fakulti Pendidikan: Universiti Kebangsaan Malaysia.

[10] Kementerian Pendidikan Malaysia. 2014. Kemahiran Berfikir Aras Tinggi Aplikasi di Sekolah. Kuala Lumpur.

[11] Kementerian Pendidikan Tinggi. 2012. Pelan Pembangunan Pendidikan Malaysia 2013-2025. Kuala Lumpur: Kementerian Pendidikan Malaysia.

[12] W. Anderson and D. R. Krathwohl. 2001. A Taxonomy for Learning, Teaching and Assessing: A Revision of Bloom's Taxonomy of Educational Objectives. New York: Longman.

[13] Lembaga Peperiksaan Malaysia. 2013. Pentaksiran Kemahiran Berfikir Aras Tinggi. Kementerian Pendidikan Malaysia. Kuala Lumpur: Penerbit Surya Sdn. Bhd.

[14] Musliha Salma. 2010. Aplikasi Kemahiran Berfikir Aras Tinggi Melalui Pembelajaran Berasaskan Masalah. Fakulti Pendidikan: Universiti Teknologi Malaysia.

[15] Mohamad Nurul Azmi Mat Nor. 2016. Penguasaan Lemahiran Berfikir Aras Tinggi (KBAT) dalam kalangan Guru Reka Bentuk dan Teknologi (RBT) Sekolah Rendah. Institut Pendidikan Guru Malaysia. Ipoh: Graduate Research in Education Seminar 2018.

[16] Mohamad Zaidir Zainal Abidin \& Kamisah Osman. 2017. Level of Knowledge, Understanding, Skills dan Performance of Science Teachers on Higher Order Thinking Skills. Fakulti Pendidikan Universiti Kebangsaan Malaysia: Bangi. Journal of Advanced Research in Social and Behaviour Sciences.

[17] S. Rajendran. 2001. pengajaran Kemahiran Berfikir Aras Tinggi: Kesediaan Guru Mengendalikan Proses Pengajaran dan Pembelajaran. Fakulti Sains Kognitif dan Pembangunan Manusia: Universiti Pendidikan Sultan Idris.

[18] Norafidah Noralidin \& Juliana Osong. 2013. Meningkatkan Tahap Kemahiran Berfikir Aras Tinggi (KBAT) dalam Pengajaran dan Pembelajaran Bahasa Malaysia Melalui Komuniti Pembelajaran Profesional $(K P P)$ Jabatan Penyelidikan Inovasi dan Profesionalisme Keguruan. IPG Kampus Gaya: Kota Kinabalu Sabah.
[19] Nor Hasmaliza Hasan. 2016. Persepsi guru bahasa melayu sekolah Menengah Kebangsaan terhadap Penerapan KBAT dalam pengajaran dan pembelajaran. Tesis Sarjana Pendidikan. Fakulti Pendidikan: Univeristi Kebangsaan Malaysia.

[20] Nooraini Othman \& Khairul Azmi. 2014. Thinking Skill Education and Transformational Progress in Malaysia. International Education Studies, 7(4), 27-32.

[21] Nur Hawa Hanis. 2018. Kesediaan Guru Melaksanakan Kemahiran Berfikir Aras Tinggi dalam Pengajaran. Jurnal Kurikulum \& Pengajaran Asia Pasifik. Julai 2018, Bil. 6, Isu 3.

[22] Quellmalz. 1985. Needed: Better Methods for Testing Higher Order Thinking Skills the Association for Supervision dan Curriculum Development. USA

[23] Rahimah Ahmad. 2016. Penerapan Kemahiran Berfikir Aras Tinggi Pelajar dalam Pengajaran Karangan Guru Bahasa Melayu: Satu Kajian Kes. Kertas Projek Sarjana Pendidikan. Fakulti Pendidikan: Universiti Kebangsaan Malaysia.

[24] Saemah Rahman \& Zamri Mahamod. 2017. Inovasi Pengajaran dan Pembelajaran. Kuala Lumpur: Dewan Bahasa dan Pustaka.

[25] Supramani. 2006. Penyoalan Guru: Pemangkin Pemikiran Aras Tinggi Murid. Jurnal Pendidikan: Universiti Malaya.

[26] Siti Zubaidah Mohamed. 2006. Kesan Pendekatan Penyebatian Kemahiran Berfikir dalam Pengajaran karangan deskriptif dan karangan imaginatif dalam kalangan pelajar tingkatan IV. Tesis Doktor Falsafah, Pusat Pengajian Ilmu Pendidikan, Universiti Sains Malaysia.

[27] Tomei, Laurence. 2005. Taxonomy for the Technology Domain. Information Science Publishing. London: United Kingdom.

[28] Zamri Mahamod. 2015. Kepelbagian Pelajar dan Perbersaan Pembelajaran. Bangi: Penerbit Universiti Kebangsaan Malaysia.

[29] Yee M. Heong, Jailani M. Y Widad. O, Razali. H \& Tee Tze Kiong. 2011. Penggunaan Kemahiran Berfikir Aras Tinggi Marzano dalam Penjanaan Idea http://eprints.uthm.edu.my/496/1/Yee_Mei_Heong(Dek an2010).pdf 